\title{
MARKETING EFFICIENCY ANALYSIS OF BEEF CATTLE IN ANIMAL MARKET SUKA VILLAGE TIGAPANAH SUBDISTRICT KARO DISTRICT
}

\author{
A A Sidebang, I Sembiring, E Mirwandhono, Hasnudi, and M Tafsin \\ Animal Production Study Program, Faculty of Agriculture, University of Sumatera \\ Utara, Medan 20155 \\ E-mail : averyarthur1@gmail.com
}

\begin{abstract}
The purpose of this research is to know marketing institution, marketing channel, marketing function, market structure, market behavior, market performance, marketing cost, marketing margin, marketing profit and marketing efficiency of beef cattle in animal market Suka Village TigapanahSubdistrictKaro District. The research conducted in the animal market of Suka Village TigapanahSubdistrictKaro District from March until April 2017. This research used primary data obtained from observation and interview of respondents. Determination of respondents with snowball sampling method that has 30 respondents. Secondary data is obtained from related institutions such as the Central Agency of Statistics and the Karo District Agricultural Departement. The parameters studied were marketing institution, marketing channel, marketing function, market structure, market conduct, market performance, marketing margin, farmer's share and profit to cost ratio. The results is marketing institutions involved are farmers and agent. The marketing channels are the first two channels: the farmer - the consumer and the second channel: the farmer - the agent - the consumer. Marketing functions undertaken by marketing institutions are the functions of exchange, physical and facilities. The market structure is oligopoly and oligopsoni. Market conduct is the practice of pricing away from dishonesty and marketing costs are not uniform and the absence of intervention from the government. Market performance is that there is no technological progress and no improvement of product quality and service maximization. Marketing margin of cannel I is Rp.0 and channel II is Rp.815.384. Farmer's share of channel I is $100 \%$ and channel II is $95.59 \%$. The profit to cost ratio of channel I is 105,86 and channel II is 2,55 . The conclusion of this research is the marketing of beef cattle in the animal market of Suka Village TigapanahSubdistrictKaro District has been efficient.

Keyword : efficiency, beef cattle, market
\end{abstract}

\section{Introduction}

The development of livestock is not only aimed at increasing the production and income of farmers but expanded to include integrated agribusiness development. The development of livestock business is done synergistically, starting from upstream to downstream and not stopping only at production level but also as post-harvest actor like processing and marketing.

A problem in developing countries especially in Indonesia is the lack of attention in the field of marketing. The marketing efforts of beef cattle that are kept by the people are mostly controlled by marketing institutions that have large scale business such as blantik, collecting merchant and butcher. 
Animal market is a place to transact the sale and purchase of animals that include cows, buffalo, goats and sheep. Animal Market Suka Village is one of the animal market in Karo Regency which operates every Tuesday from 09.00 WIB until 17.00 WIB. Cattle sold in this animal market are cows and buffalo. This animal market is one of the potential area of Karo Regency in the field of animal husbandry and is very suitable to develop marketing efficiency of beef cattle. The purpose of this research is to know the channel form and marketing function of each marketing agency of beef cattle, to know the structure, behavior and performance of beef cattle market, to examine the cost, margin and profit of marketing institutions and to assess the efficiency level of beef marketing in the animal market Village Suka District TigapanahKaro.

\section{Materials And Methods}

\subsection{Place and time of research}

This research was conducted at PasarHewanSuka Village, Tigapanah Sub-district, Karo Regency. The study was conducted from March to April 2017.

\subsection{Types and Data Sources}

This study uses primary and secondary data that are qualitative and quantitative. Primary data was obtained by direct observation and direct interviews using questionnaires (questionnaires) to respondents and marketing institutions involved in the process of marketing beef cattle that took place in the SukaKaro Village animal market. Secondary data were collected through various literatures used as reference material to support the primary data during the research process.

\subsection{Method of collecting data}

This research was conducted by using primary data which was done by observation and interview by using questionnaire. The questionnaire contains open and closed questions (structured). Open questions include questions whose answers are descriptions or are not provided while closed questions contain questions whose answers have been provided. Determination of marketing agency respondents conducted by snowball sampling method.This method is done with the aim to trace the flow of products and the involvement of marketing institutions in performing its marketing functions. Method of Processing and Data Analysis

The method used in processing and analyzing data in this research is qualitative and quantitative method. Qualitative analysis uses descriptive method to identify systematic and detailed description of marketing channel, marketing channel function, market structure, market behavior and market beef cattle market at DesaSuka village. Qualitative analysis is presented and analyzed in the form of simple description and tabulation. While quantitative analysis is used to identify and analyze marketing margins, farmer's share, and profit-to-cost ratio for each marketing agency and processed using Microsoft Excel software which is then presented in tabular form. Furthermore, these analyzes are used to assess the marketing efficiency of beef cattle in Suka Village's animal market.

Analysis of institutions, channels and marketing functions

Marketing institutions are analyzed to find out what marketing institutions are involved in the beef cattle marketing system at Suka Village's animal market. Thus information will be obtained about the flow of products that can form a marketing channel from breeder level to final consumer level. Marketing function analysis needs to be identified to know marketing activities undertaken by each marketing agency in distributing products from farmers to final consumers. These marketing institutions generally perform the functions of exchanges (sales and purchases), physical functions (packaging, transport, and storage) and facility functions (financing, risk cover, market information and standardization) [1].

Analysis of structure, behavior and market performance

This analysis uses the SCP approach (Structure, Conduct, Performance). The market structure in the analysis with 3 indicators is the size of the number of buyers and sellers must be plenty so as to ensure the existence of an adequate competition intensity in terms of price and product quality, the 
freedom of entry and exit market for marketing institutions, the number of buyers should be adequate thereby encouraging increased investment efficiency in the marketing of livestock commodities. Market behavior in the analysis with four indicators of pricing practices should allow for the grading and standardization of livestock commodities, marketing costs should be uniform, pricing should be free of conspiracy, dishonest or illicit trade practices, the form of price policy should be able to improve product quality and consumer decision making. Market performance in the analysis with 4 indicators that there should be technological progress, the orientation for the development of marketing institutions, the increased efficiency of resource use, the improvement of product quality and the maximization of marketing services at the lowest possible cost [2] .

\subsection{Marketing margin analysis}

Margin marketing is to know the amount of money received each marketing agency beef cattle with the price paid consumers to buy beef cattle. To do a marketing margin analysis can be calculated by the formula:

Information :

$$
\mathrm{MPi}=\mathbf{H J i}-\mathbf{H B i}
$$

Mpi: Margin of marketing agency i (marketing channels 1, 2 and 3)

Hji: Selling Price of marketing agency ke-i (Rp / head)

Hbi: The purchase price of marketing agency i ( Rp / head)

Criteria decision-making is the smaller the value of marketing margins, the more efficient a marketing. In addition, marketing can be said to be efficient if the value received by the breeder or producer of beef cattle is greater than the overall marketing margin.

Farmer's share analysis

Farmer's share is the percentage of prices received by farmers compared to the selling price of the trader. Farmer's share in a marketing activity can serve as the basis or benchmark marketing efficiency. The higher the percentage rate of farmer's share received by farmers, it is said to be more efficient marketing activities undertaken and vice versa. Farmer's share can be calculated using the formula:

Information :

$$
\text { FS }=\text { HP/HK } \times 100 \%
$$

FS: Farmer's Share

HP: Manufacturer Price (Rp / head)

HK: Final Consumer purchasing price ( $\mathrm{Rp} /$ head)

\subsection{Profit and cost ratio analysis}

The profit-to-cost ratio can be used to determine the efficiency of a marketing system by comparing the marketing benefits gained to marketing costs incurred by the marketing agency. Marketing can be said to be efficient if the profit-to-cost ratio is equally distributed across all marketing institutions and is positive. Here is the formula of profit to cost ratio.

Information:

Ratio of profit to cost $=\pi \mathrm{i} / \mathrm{Ci}$

Пi: The profit of the i-beef cattle marketing agency ( $\mathrm{Rp} / \mathrm{head})$

Ci: Cost of marketing agency of beef cattle level i ( $\mathrm{Rp} / \mathrm{head})$.

\section{Results and Discussion}

\subsection{Marketing Institution}

Marketing is one of the main activities undertaken by farmers and marketing institutions to gain the maximum profit in marketing a commodity or a particular product. Based on the results of marketing research beef cattle in the animal market Suka Village there are two marketing institutions that play a role in the marketing of beef cattle, breeders and collectors traders. 


\subsection{Breeders}

Breeders are producers of beef cattle that also act as marketing institutions. Farmers play a role in selling beef cattle directly to consumers in Suka Village's animal market. Farmers who come to the animal market to sell their beef cattle are from Karo District which includes Tigapanah, Munthe, Kabanjahe, SimpangEmpat, Dolat Rakyat and other districts around Karo. Not only beef cattle ranchers from Karo Regency who came to the animal market but also from Simalungun and Karo regency.

\subsection{Collectors traders}

The collecting trader plays the beef cattle from the farmer who lives around his residence and sells it back to the Suka Village animal market. The collecting traders who come to the animal market come from Karo Regency, Simalungun District, Binjai and the area around Karo Regency.

\subsection{Marketing channel}

A marketing channel is a set of actors who channel all the functions used to channel their products and ownership status from producer to consumer. Based on the results of marketing research beef cattle in the animal market Suka Village Tigapanah District Karo Regency has two marketing channels. This can be seen in the following figure:

BREEDER CONSUMENT

Picture 1. Marketting Channel I

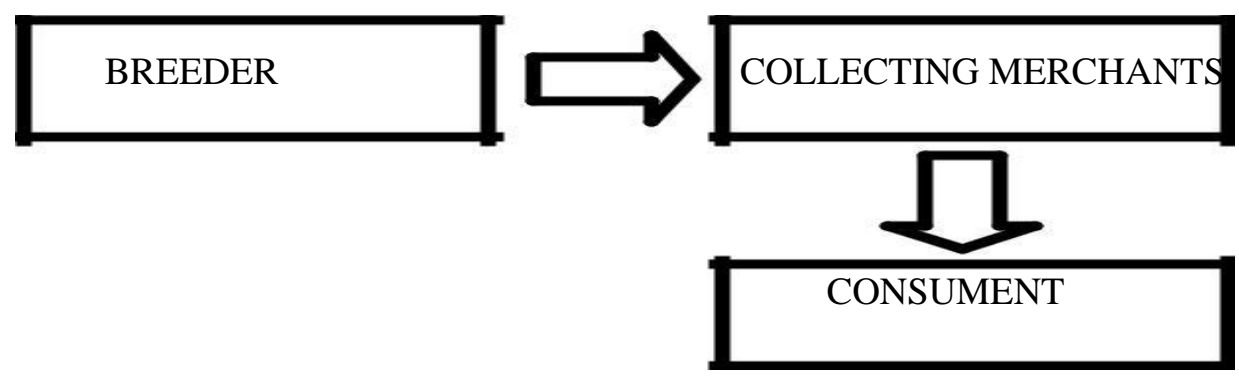

Picture 2. Marketting Channel II

Marketing channel I is also called 1 level marketing because it involves a marketing agency that is a breeder. In this channel the beef cattle rancher immediately brings his beef cattle to the animal market for sale. The reason the farmer directly sells it to the animal market because of the dwelling which is adjacent to the animal market, all profit from the sale to the breeder and want to see and buy the beef cattle directly belonging to other breeders. Of the respondents found in the market of animals there are 17 people who play a role in their marketing channel I come from Karo District such as Suka Village, Kabanjahe, Lingga, Dolat Rakyat, LinggaJulu, Munthe, SimpangEmpat and Tigapanah and some are from outside Karo from Siantar.

Marketing channel II is also called 2-level marketing because it involves two marketing institutions namely breeders and collecting traders. The collecting trader buys beef cattle from the farmers who are around his residence who will then sell him back in the animal market. Of the respondents found in the animal market there were 13 people involved as collecting traders. They come from the Karo District, Simalungun and Binjai Regencies.

\subsection{Marketing Function}

The function of marketing is a function performed by every component that interacts in the marketing system. The marketing function is needed to facilitate the distribution of beef cattle. The 
function of marketing agency of beef cattle in animal market Suka Village Tigapanah District Karo Regency can be seen in the following table:

\begin{tabular}{|c|c|c|}
\hline $\begin{array}{l}\text { Marketing } \\
\text { Agencies }\end{array}$ & $\begin{array}{l}\text { Marketing } \\
\text { Function }\end{array}$ & Treatment \\
\hline Breeder & $\begin{array}{l}\text { Exchange } \\
\text { Physical } \\
\text { Facility }\end{array}$ & $\begin{array}{l}\text { Sale } \\
\text { Transportation, Storage } \\
\text { Financing }\end{array}$ \\
\hline Collecting & Exchange & Sale, \\
\hline Merchant & $\begin{array}{l}\text { Physical } \\
\text { Fasility }\end{array}$ & $\begin{array}{l}\text { Purchase } \\
\text { Transportation, Storage } \\
\text { Information } \\
\text { Market, } \\
\text { Financing, } \\
\text { Collecting, } \\
\text { Coverage } \\
\text { Risk }\end{array}$ \\
\hline
\end{tabular}

Breeders perform the function of the exchange of sales function in the form of beef cattle with average selling price of Rp. 18,102,941 per head. Physical function performed is the transport and storage functions. Transportation function carried out by the breeder is the transportation of beef cattle from the dweller of the farmer to the animal market by using pick-up and truck car. The average cost incurred for transportation costs is Rp.112.353 per head. The storage function carried out by the breeder ie when the cattle are not sold in the animal market then the breeder will bring her back home and kept her back for sale next week in the animal market. The function of the facilities undertaken by the breeder is the function of financing. In this case the farmer undertakes all marketing financing such as transportation costs, feed costs in the market, permit and retribution fees, veterinary inspection fees and loading and unloading costs.

The collecting trader performs the exchange function ie the purchasing function and the sales function. The average price of beef cattle purchased by collecting traders from breeders is Rp. $17,665,385$ per head and the average selling price of beef cattle sold by collectors in the animal market is Rp.18.480.769 per head. The physical function performed by collecting merchants is the transport function and the storage function. Transportation carried out is the transport of beef cattle from the residence of collectors to the animal market by using pick-up and truck cars which have an average transportation cost of Rp. 170.000 per head. The collecting traders will bring the beef cattle back home and keep them back as well as brought again next week to the animal market for sale. The function of the facilities performed by collecting merchants is market information, financing, collection, risk aversion. Collecting traders inform market information to the farmers around his residence both in terms of beef cattle prices and demand for beef cattle in the animal market. Collector traders undertake financing during the marketing of beef cattle such as transportation costs, feed costs in the market, licensing fees and market charges, inspection fees and animal health and loading and unloading costs. The collection function is carried out by collecting merchants by collecting beef cattle ready for sale to the animal market from their residence. The collecting traders also put the risk of livestock on sale to the animal market in terms of both price and stress level of beef cattle. 


\subsection{Market Structure}

The market structure is the institutional characteristic of a market that determines the relationship between one seller and another, between the buyer and the seller, and the relationship between the seller in the market and the potential seller going in and out of the market.

\subsection{The size of sellers and buyers of beef cattle}

Based on the observation in animal market Suka Village is known that the size of sellers and buyers very much. In the market the animal not only has one seller or one buyer resulting in price and product competition. In terms of the seller then the animal market is oligopoly market and in terms of buyers then the animal market is oligopsoni market. With many sellers and buyers in the animal market of Suka Village, Tigapanah Sub-district, Karo District, it was decided that the marketing of beef cattle in the animal market has met the criteria of marketing efficiency.

\subsection{There is freedom in and out of the market}

Based on observations in animal market Suka Village is known that sellers and buyers are free to exit the market. Those who do activities in the veterinary market are not required to obtain permission from any party, either from government or other institutions. With the freedom in and out of the market, the marketing of beef cattle in the animal market of Suka Village, Tigapanah Sub-district, Karo Regency, has met the criteria of marketing efficiency.

\subsection{The number of buyers should be sufficient}

Based on the observation in animal market Suka Village is known that buyer of beef cattle always coming every week to the animal market to buy beef cattle. This is supported by the continuity of market activity that every week despite the national holiday and sold more than half the number of beef cattle offered by the sellers. In this case the demand for beef cattle in the animal market continues and remains. With the existence of an adequate number of buyers then marketing beef cattle in the animal market Suka Village District TigapanahKaro has met the criteria of marketing efficiency.

\subsection{Market Behavior}

Market behavior indicates the behavior of marketing institutions in particular market structures, especially what forms of decision should be taken in the face of various market structures. Market behavior includes selling, purchasing, pricing, and trading strategy.

\subsection{Pricing practices}

Practices of beef cattle prices in the animal market DesaSuka is viewed on the basis of price taker and price maker. The price of beef cattle in the animal market is adjusted to the agreement between the seller and the buyer. Seller and buyer in pricing by considering the estimated factor of beef weight. Prices applicable in the animal market considering the weight of beef that is per kilogram with the price Rp.125.000 and per can Rp.1.8 million. So the animal market of Suka Village, Tigapanah Sub-district, Karo Regency, in the practice of determining the price of beef cattle has made standardization that has been known together by market players. With the practice of pricing that allows the standardization of beef cattle, the practice of pricing in the animal market of Suka Village, Tigapanah Sub-district, Karo Regency, has met the criteria of marketing efficiency. 


\subsection{Marketing costs}

The criteria used to determine market behavior is that marketing costs should be uniform. Marketing costs represent the overall cost incurred to distribute beef cattle from farmers' hands to the hands of consumers in Suka Village's animal market. Marketing expenses incurred by market participants generally include transportation costs, market feed costs, licensing fees and user charges in the market, veterinary inspection fees and loading and unloading costs. The cost of marketing beef cattle in the animal market is not uniform, this is because the distance between market participants with each other is different so the cost of transportation is not the same and the feed given is not the same price. The uniform cost is the cost of permit or levy set at Rp 10,000 and animal health costs of Rp.20.000. The marketing cost of beef cattle in the animal market Desa Suka Kecamatan Tigapanah Karo District is not uniform and this does not meet the criteria of marketing efficiency.

\subsection{Pricing}

The criteria used to determine the market behavior of pricing should be free of conspiracy, dishonest practices or illicit trade. Determination of the price of beef cattle sold in animal market Suka Village based on the estimated beef cattle. The beef cattle price determination system in the animal market is done by sellers and buyers by seeking agreement. Generally they use the standard price applicable in the animal market that is per kilogram of Rp.125.000 and per can Rp.1.8 million. So it can be concluded that the determination of price of beef cattle in the animal market of Suka Village, Tigapanah Sub-district of Karo Regency is indicated there is no conspiracy, dishonest or illicit trade, it has fulfilled the criteria of marketing efficiency.

\subsection{Government intervention}

The criteria used to determine market behaviorie government intervention in the form of price policy should be able to improve product quality and consumer decision making. Prices of beef cattle in the animal market Suka Village ranging from breeders to consumers no intervention or intervention from the government. The price of beef cattle in accordance with the agreement between the seller and the buyer by using the prevailing market price standards. The government has no authority or interference

in the determination of the lowest price and the highest price of beef cattle marketed in the animal market. The government only has authority in issuing animal health certificates required by market participants. So it can be concluded that the absence of government intervention in the form of pricing to improve beef cattle products in the market of Suka Village TigapanahSubdistrictKaro Regency, this does not meet the criteria of marketing efficiency.

\subsection{Market Taste}

Market performance is the result of a final decision taken in conjunction with the process of bargaining and market competition.

\subsection{There are technological advances}

The criterion for assessing the market's performances is technological progress. Marketing beef cattle in the animal market DesaSuka does not take advantage of technological advances in the marketing process. The absence of scales in the animal market so that weight determination is done on an estimate basis. The marketing of beef cattle is done traditionally by bringing beef cattle directly to the market and buyers also directly buy the beef cattle. The absence of marketing beef cattle online system like most marketing products that many people do. The reduction of beef cattle from pick-up or truck cars is also only done manually and is assisted by mounds of soil around the animal market. Technological advances in the marketing of beef cattle in the animal market of Suka Village, Tigapanah Sub-district, Karo District, are completely absent, so this does not meet the criteria of marketing efficiency. 


\subsection{Orientation of the development of marketing institutions}

The criterion used to assess market behavior is the orientation for the development of marketing institutions. In the marketing of beef cattle in the animal market DesaSuka there is no orientation in the development of marketing institutions of beef cattle. The marketing agencies involved in the marketing of beef cattle in the veterinary market stand alone without the help or intervention of others. For example, in terms of capital, marketing institutions do not get help from banks, business entities and cooperatives. In the field of product quality improvement, marketing agencies are also not assisted by any party. So the orientation of the development of marketing institutions in the marketing of beef cattle in the animal market of Suka Village, Tigapanah Sub-district, Karo District, is not there, then this does not meet the criteria of marketing efficiency.

\subsection{Increased resource efficiency}

The criteria used to look at the market's performance are the increased efficiency of resources. In marketing beef cattle in the animal market DesaSuka there has been an increase in the efficiency of resources conducted by marketing institutions. Increased efficiency of resources is supported by the existence of marketing institutions that act as breeders and collectors as well. This is done to increase profits and utilize resource efficiency. Marketing agencies also bring animal feed from their respective homes to reduce marketing costs. With the increased efficiency of these resources, the marketing of beef cattle in the animal market of Suka Village, Tigapanah Sub-district, Karo Regency, has met the criteria of marketing efficiency.

\subsection{Improved product quality and marketing service maximization}

The criteria used to assess market performance are improving product quality and maximizing marketing services at the lowest possible cost. Products marketed in the animal market are live beef cattle without any processing and product quality improvements. Both breeders and collectors bring in live beef cattle

directly to the animal market in the absence of a sorting process. Marketing of beef cattle in the animal market DesaSuka does not maximize marketing services. This is evidenced by the seller utilizing the existing loading and unloading services in the animal market so that marketing costs in terms of loading and unloading can not be reduced. So it can be concluded that the marketing of beef cattle in the Simal Village market of Tigapanah sub-district of Karo Regency has not improved product quality and maximization of marketing services so that this does not meet the criteria of marketing efficiency.

\subsection{Marketing Margin}

Marketing margin is used as an indicator of marketing efficiency. The amount of marketing margins on different marketing channels may differ depending on the length of the marketing channel and the activities that have been implemented and the benefits expected by the marketing agency involved in a product marketing. The marketing margin represents the difference between the price received by the breeder and the price paid by the consumer of beef cattle in the animal market. The smaller the marketing margin of a product the better the marketing channel. The amount of profits and costs incurred by each marketing agency involved in the marketing of beef cattle can be identified by marketing margin analysis. 


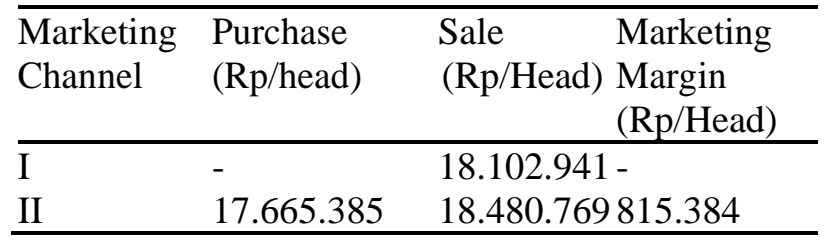

From the above table it is known that marketing margin on marketing channel I is Rp.0. This is because the farmer who directly sell his beef cattle to the consumer in the Suka Village animal market so as to provide higher benefits to farmers. On channel II has a marketing margin of Rp.815.384. This is because the average purchase price of beef cattle is Rp.17.665.385 per head and its selling price is Rp.18.480.769, so the marketing channel II gives less profit to the breeder.

\subsection{Farmer's Share}

Farmer's share is the percentage of prices received by farmers compared to the selling price of retailers. Farmer's share in a marketing activity can serve as the basis or benchmark marketing efficiency. The higher the percentage rate of farmer's share received by farmers, it is said that the more efficient the marketing activity is done and the lower the percentage rate of farmer's share received by the farmer [2], the lower the efficiency level of the marketing.

\begin{tabular}{ll}
\hline Marketing Channel & Farmer's Share (\%) \\
\hline I & 100 \\
II & 95,59 \\
\hline
\end{tabular}

From the table above can be seen that the percentage of the price received by farmers (farmer's share) on channel I is $100 \%$ because the farmers directly market their beef cattle to consumers in the animal market Suka Village. There is no price difference at the producer level and the consumer level on marketing channel I so that the price received by the breeder is $100 \%$. In marketing channel II, the percentage of the price received by the breeder is $95.59 \%$. This is due to price differences at the producer and consumer level. The price at the producer level is Rp.17.665.385 and the price at the consumer level is Rp.18.480.769 so the farmer's share on this marketing channel is $95.59 \%$.

\subsection{Ratio of Profit to Cost}

The profit-to-cost ratio can be used to determine the efficiency of a marketing system by comparing the marketing benefits gained to marketing costs incurred by the marketing agency. Marketing can be said to be efficient if the profit-to-cost ratio is evenly distributed on all marketing agencies and positive values.

\begin{tabular}{|c|c|c|c|}
\hline Marketing & Profit & $\begin{array}{c}\text { Cost } \\
(\mathrm{Rp} / \mathrm{Head}\end{array}$ & Profit \\
\hline Channel & (Rp/Head) & ) & $\begin{array}{l}\text { to } \\
\text { Cost } \\
\text { Ratio }\end{array}$ \\
\hline I & 17.933 .529 & 169.412 & 2105,86 \\
\hline II & 585.385 & 230.000 & 02,55 \\
\hline
\end{tabular}

From the table above it can be seen that the marketing channel I profit to cost ratio is 105,86 . This is because the farmer sells directly his beef cattle to the animal market without going through an 
intermediary and the benefits gained will be entirely to the breeder. On marketing channel II the profit to cost ratio is 2.55 . This is because beef cattle breeders are sold through an intermediary that is collecting traders. So the ratio of profit to the cost of marketing of beef cattle is 2.55 .

\section{Conclusions}

Marketing institutions involved in the marketing of beef cattle in the animal market Village SukaTigapanah Sub-district of Karo Regency is a breeder and gathering trader. These marketing institutions form two marketing channels: the first channel: the farmer - the consumer and the second channel: the farmer - the collecting merchant - the consumer. Marketing functions undertaken by farmers include the function of the exchange of sales, physical functions of transport and storage, the function of facilities ie financing. Marketing functions performed by collecting traders include the exchange function of sales and purchases, the physical functions of transport and storage, the function of the facility ie market information, financing, collection and risk coverage.

Marketing of beef cattle in the market Animal SukaDesa has a market structure in which the number of sellers and buyers are numerous so as to enable competition, the freedom of market entry and adequate buyers. This market behavior is the practice of pricing allows the standardization, in the price determination there is no conspiracy and dishonesty and there is no illegal trade. In terms of marketing costs is still not uniform and the absence of government intervention in the field of price and product improvement. The market presence in this market is that there is no technological progress, the lack of development orientation of the marketing institution and the absence of product quality improvement and the maximization of services and in the case of increased resources already done by market participants.

Through the marketing channel of beef cattle in the animal market Suka Village Tigapanah District Karo Regency there is a marketing margin on the first channel of Rp.0 and marketing margin on the second channel is Rp.815.384. Farmer's share on the first channel is $100 \%$ and the second channel is $95.59 \%$. The ratio of profit to the cost on the first channel is 105.86 and the second channel is 2.55 . Judging from marketing margin, farmer's share and profit-to-cost ratio, beef cattle marketing in Suji Village Tigapanah sub-district of Karo Regency is stated to be efficient.

\section{References :}

[1] Widyaningtyas, Dewina.,Raharto Sugeng, danAgustinaTitin. 2014. Analisis Efisiensi Pemasaran Kopi Arabika di Desa Karangpring Kecamatan Sukorambi Kabupaten Jember (Efficiency of Arabica Coffee Marketing in Karangpring Village Sukorambi Sub-district, Jember District). Berkala Ilmiah Pertanian 1(1): xx-xx.

[2] Sudiyono, Armand. 2004. Pemasaran Pertanian (Agricultural Marketing). UMM Press, Malang.

[3] Limbong W.H., Sitorus. 1987. Pengantar Tataniaga Pertanian (introduction to agricultural trading). Fakultas Pertanian Institut Pertanian Bogor, Bogor. 